\title{
FREE EYE EXAMINATION POLICY FOR PRIMARY SCHOOL STUDENTS NORTH LARANGAN, BANTEN
}

\author{
Zulkarnain Febri Wicaksono'), Adang Bachtiar²) \\ 1)Masters Program in Public Health, Universitas Indonesia \\ 2)Department of Health Policy Administration, Faculty of Public Health, \\ Universitas Indonesia
}

\begin{abstract}
Background: Playing videogames or looking at smartphone for long period of time may cause visual dysfunction such as myopia and amblyopia. This visual dysfunction also impairs learning activity among primary students. Vision screening for schoolaged children becomes important to detect the eye problem. This study aimed to investigate the free eye examination policy for primary school students North Larangan, Banten.

Subjects and Method: This was a descriptive qualitative study conducted at North Larangan, Tangerang, Banten, in July 2019. A sample of 6 informants and 28 primary students were selected for this study. The informants were including chief of the citizen association, chief of the neighborhood association, optic owner, refractionist, parents, and primary student. The theme of this study was analysis of the free eye examination policy for primary school students. The data were collected by in-depth interview and direct observation. The data were analyzed by content analysis.

Results: The citizen association 005 collaborated with Remaja optic for free routine eye examination program for primary school students and health education. The results of the eye examination were 20 students had $\geq-1.00,4$ students had $\geq-2.00,3$ students had $\geq-3.00$ and 1 student had $\geq-4.00$. This program had just been implemented, and its effect on the reduction of visual dysfunction had not been identified. Eye health education was carried out by refractionist for students and parents. The citizen association o05 made a regulation imposing for 4 hour compulsory study at home in order to reduce time for playing online game.

Conclusion: Free routine eye examination for primary school students in citizen association 005 has been started, but its effect on the reduction of visual dysfunction has yet to be identified. The compulsory study hour has also been implemented although its enforcement is weak.
\end{abstract}

Keywords: free routine eye examination, primary school students.

\section{Correspondence:}

Zulkarnain Febri Wicaksono. Masters Program in Public Health, Universitas Indonesia, Depok, West Java. Email: Zulkarnain3209@gmail.com Mobile: 083840987872. 